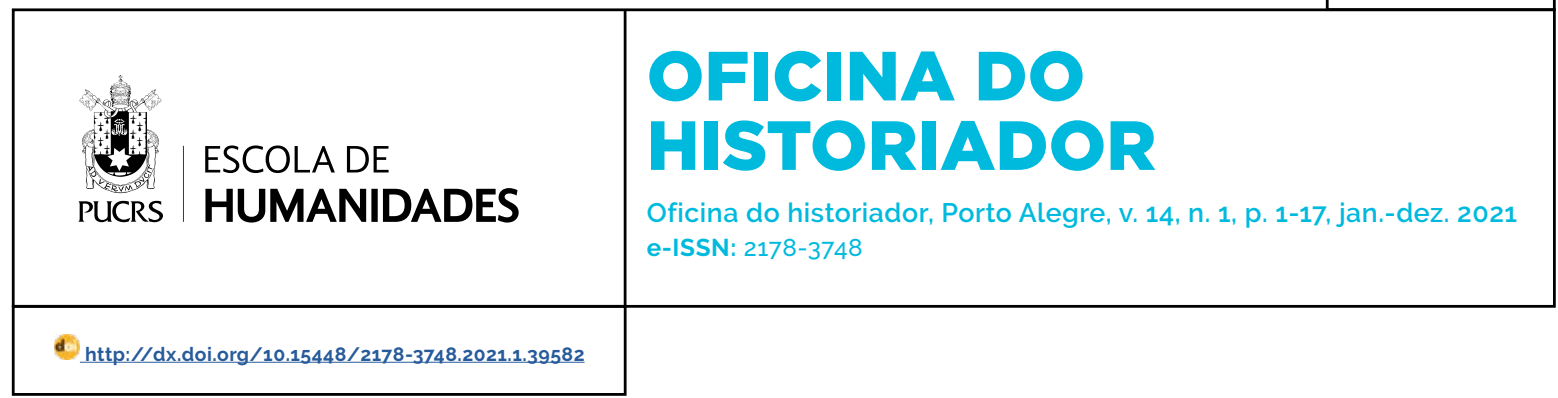

SEÇÃO: DOSSIÊ

\title{
OS SERTÕES ONSCREEN IN PAULO GIL SOARES'S O HOMEM DE COURO (1969/70)
}

OS SERTÕES NA TELA EM O HOMEM DE COURO DO PAULO GIL SOARES (1969/70)

Victoria R. Broadus ${ }^{1}$

orcid.org/0000-0002-2774-745X

vrb7@georgetown.edu

Received on: Nov. $20^{\text {th }}, 2020$ Approved on: Feb. $15^{\text {th }}, 2021$. Published on: July $29^{\text {th }}, 2021$.

\section{(c) (1)}

Artigo está licenciado sob forma de uma licença Creative Commons Atribuição 4.0 Internacional.
Abstract: This article examines filmmaker Paulo Gil Soares's early work with a particular focus on the documentary O Homem de Couro (1969/70), in the context of Brazil's military dictatorship (1964-85), the documentary-film initiative known as the "Farkas Caravan," and 1960s-era Brazilian documentary more broadly. I argue that Soares's $O$ Homem de Couro represents an audiovisual renewal and revision of Euclides da Cunha's portrayal of the northeastern vaqueiro in Os Sertões (1902). In the film, Soares's depiction of the vaqueiro served as both a tribute to these national folk heroes and a reminder to viewers that da Cunha's scathing turn-of-the-century portrait of the northeastern social order should not be considered a relic of the past. Timeless northeastern verses drive the narrative, reinforcing that message. In this way, Soares made a film that was both beautiful and denunciatory without resorting to pedagogical voiceovers or orthodox dogma. He meanwhile updated key elements of Os Sertões for the 1960 s and '70s. Soares offered subjectivity that was lacking in da Cunha's account, discrediting da Cunha's nineteenth-century biological and geographical determinism. He also documented inauspicious shifts in this labor market that threatened the vaqueiro's future. In the early 1970s, Soares would go on to found the influential documentary-journalism program Globo Repórter. By focusing on his work with the Farkas Caravan, this article contributes a new perspective on a key but previously overlooked element in the formation of the Brazilian school of documentary film and journalism, and on the enduring legacies of da Cunha's work.

Keywords: Brazilian documentary, Caravana Farkas, Os Sertões

Resumo: O presente artigo se propõe a analisar a obra do diretor Paulo Gil Soares, com ênfase no documentário O Homem de Couro (1969/70), no contexto da ditatura militar (1964-85) e o projeto de produção de documentários conhecido como a "Caravana Farkas". Mais especificamente, o artigo tem por objetivo traçar as conexões entre a obra de Paulo Gil Soares e a obra de Euclides da Cunha, focando nos paralelos entre $O$ Homem de Couro e a apresentação do vaqueiro no livro Os Sertões (1902). A representação do vaqueiro no documentário serviu como tributo a estes heróis populares nacionais, além de expressar a força duradoura do retrato critico da ordem social nordestina em Os Sertões quase setenta anos após a sua publicação. Dessa forma, Soares conseguiu fazer um documentário-denúncia primoroso sem recorrer a voz-over pedagógica ou afirmações dogmáticas. Ao mesmo tempo, Soares atualizou o retrato do da Cunha para os anos 60-70: O Homem de Couro oferece subjetividade que faltava no trabalho deste, desmentindo o determinismo biológico e geográfico do da Cunha, e retrata, de forma sutil, mudanças desfavoráveis no trabalho do vaqueiro sob o regime autoritário. Poucos anos após a realização do documentário, Soares fundaria o Globo Repórter, levando o seu estilo de documentário jornalística a um público enorme por todo o Brasil. Este artigo sobre os seus primeiros passos artísticos analisa uma peça-chave porém pouco estudada de um periodo formativo do documentário e telejornalismo brasileiro, e revela mais um exemplo do legado duradouro do trabalho de Euclides da Cunha.

Palavras-chave: Documentário brasileiro, Caravana Farkas, Os Sertões 


\section{Introduction: Documentary Film in} $1960 s$ Brazil

The 1960s was a decade of revolutions, and a revolution in documentary filmmaking helped capture them all. The advent of both lightweight $16 \mathrm{~mm}$ cameras and portable synchronous tape recorders allowed filmmakers for the first time to record sound and image anywhere, simultaneously, and with relative ease. The manageable equipment also allowed for smaller, more agile film crews: a few filmmakers with an idea could throw their equipment in a car and go. It was a watershed in the history of documentary filmmaking.

This technological transformation was particularly important in Brazil, a massive country with countless pockets of isolated populations that filmmakers had hardly dreamed of capturing. Thomaz Farkas (1924-2011) was best known for his photography, but he was also a central figure in the development of Brazilian documentary film. In his 1972 doctoral dissertation on the subject, he wrote of the power of documentary film in the Brazilian context: "In Brazil, [documentary film] takes on greater meaning... when one considers the distances, not only geographic but also cultural. How better to present these diverse cultural manifestations, connected to the specific realities of each region of the country, than through documentary film?" (FARKAS, 1972, p. 2). ${ }^{2}$

Budding Brazilian filmmakers hoped that depicting previously inaccessible corners of their nation would awaken the privileged urban elite (mostly their own milieu) to the realities of their stunningly diverse yet dramatically unequal country. As Farkas suggested, part of capturing that diversity meant documenting popular cultural practices that, for the filmmakers as well as for a foundational national literary tradition before them - turn-of-the-century writers such as Capistrano de Abreu and Euclides da Cunha - constituted the heart of the Brazilian nation. So, in the 1960s, a band of young Brazilians who had envisioned leaving their mark as novelists, poets, playwrights or journalists turned to film as a means to get their message across and became writer-directors.

Among them was the Bahian Paulo Gil Soares (1935-2000), whose work with Farkas, specifically the documentary O Homem de Couro, is the focus of this article. In O Homem de Couro, Soares captured onscreen the northeastern vaqueiro, a Brazilian folk hero much like his counterparts across the Americas - llaneros of Colombia and Venezuela, Peruvian morochucos, Mexican vaqueros and U.S. cowboys. For centuries, the vaqueiro of the Brazilian sertão was guardian of the precious stock around which an entire economy revolved, "[P]rotagonist of the greatest socioeconomic and cultural phenomenon of settlement and unification in the entire Northeast" (QUEIROZ, 2010, p. 72). ${ }^{3}$ Euclides da Cunha had paid tribute to the vaqueiro hero in Os Sertões, a foundational literary work for Brazil and for Soares personally. I argue here that Soares's film O Homem de Couro represents an audiovisual renewal and revision of da Cunha's turn-of-the-century portrayal of the vaqueiro. The film captured da Cunha's admiring gaze and denunciatory message, updated for the late 1960s.

Soares's adaptation of da Cunha shows the ways in which Brazilian documentary filmmakers both took advantage of and reaffirmed the enduring significance of such influential Brazilian works during this crucial period. In doing so, it also shows the extent to which those filmmakers carried on the tradition that Antônio Cândido called the "most characteristic and original feature of our [Brazilian] thought." In Literatura e sociedade (1965), Cândido wrote of early-twentieth-century intellectual interpretations of Brazil:

\footnotetext{
Original: "No Brasil, ele [o filme documentário] adquire um significado mais amplo ... quando se pensa nas distâncias, não somente geográficas mas também culturais. Como apresentar as diferentes manifestações culturais, ligadas a uma realidade especifica em cada região do país, senão através do filme documentário?" A note on translations: All translations are my own except the published translations of Os Sertões that appear in footnotes below, which are taken from the Elizabeth Lowe translation (2010). Throughout the article, I have opted to include the English translation of Portuguese quotations in the body of the text, with the original Portuguese in a footnote, except in cases where the original Portuguese is key to identifying parallels between film and book. The latter include citations of $O$ Homem de Couro and Os Sertões, which I have left in the original Portuguese in the body of the text, with translations in the footnotes. For some very brief phrases I have included both original and translation in the text itself.

3 Original: "protagonista do maior fenômeno sociocultural-econômico de fixação e unidade em toda a região Nordeste."
} 
The powerful magnet of literature interfered with the sociological tendency, giving birth to that mixed genre of essay, constructed in the confluence of history and economics, philosophy or art, which is a very Brazilian manner of investigating and discovering Brazil and to which we owe the not very literary Historia da Literatura Brasileira, by Silvio Romero, Os Sertões, by Euclides da Cunha, Populações meridionais do Brasil by Oliveira Viana, the work of Gilberto Freyre and Raizes do Brasil by Sérgio Buarque de Holanda. It would not be an exaggeration to say that this type of essay - which combines, with greater or lesser results, imagination and observation, science and art - constitutes the most characteristic and original feature of our thought (CÂNDIDO, 1985, p. 130). ${ }^{4}$

That "mixed genre" approach lent Os Sertões, in particular, a decidedly cinematic quality. As Ilan Stavans has pointed out, the book "exhibits the features of good screen writing," with narrative points shifting like "a moving camera's eye" (STAVANS, 2010, p. xix), features that likely stood out to filmmakers. Soares's film and larger body of documentaries meanwhile exhibit just such a mixture as Cândido suggested: romantic lore, striking art, and gritty reality. History, social sciences, popular memory, and the writer-director's subjective impressions blend, just as in da Cunha's work.

By bringing da Cunha's portrait of the vaqueiro to the screen and showing that life in the sertão still largely aligned with that depiction, Soares presented a beautiful and scathing critique of national injustices without appealing to dogma or adhering to the expectations of the orthodox left. ${ }^{5}$ Building on an approach taken by Humberto Mauro with films like Aboios e cantadores (1954), Soares denounced authoritarian modernization by documenting this remote way of life onscreen. Song and verse, rather than the standard didactic voiceover, do the work of inserting doubt about the hero's lot in life. What's more, by evoking da Cunha, Soares reinforced the vaqueiro's stature as both a national folk hero and a symbol of the country's foundational inequities, inequities that the authoritarian regime did its best to obscure and ignore. Soares's revisions of da Cunha's account meanwhile re-examined aspects of that work that were, by the mid-twentieth century, decidedly outmoded.

One such revision was to provide subjectivity that was lacking in Os Sertões: the viewer gets to know individual vaqueiros in this film. We hear their stories and their work songs, aboios that manifest, as Medina and Medina have written, "deep and original sentiments of and about the aboiador (singing vaqueiro) himself, his history and the world around him" (MEDINA \& MEDINA, 2017, p. 52). ${ }^{6}$ Popular verses, "mirrors of the sertão mentality," as Luiz da Câmara Cascudo wrote, meanwhile drive much of the narrative, blurring those individuals with their forebears and with the collective (CASCUDO, 1984, p. 19). This has the effect of both exalting their legendary work and revealing the persistence of cyclical injustices, linking the vaqueiros onscreen back to da Cunha's heroes. A second key revision was the emphasis on specific plights of the 1960s: most specifically, a shift from payment in kind to poorly remunerated and unregulated wage labor. The result is a documentary of unusual perceptiveness. It captures this way of life central to Brazil's northeastern backlands as a means of denouncing the values and policies promoted by the authoritarian military regime of 1964-85 and much of the urban upper classes more broadly.

\footnotetext{
4 Original: "O poderoso imã da literatura interferia com a tendência sociológica, dando origem àquele gênero misto de ensaio, construído na confluência da história com economia, a filosofia ou a arte, que é uma forma bem brasileira de investigação e descoberta do Brasil e à qual devemos a pouco literária História da literatura brasileira, de Silvio Romero, Os Sertões, de Euclides da Cunha, Populações meridionais do Brasil de Oliveira Viana, a obra de Gilberto Freyre e as Raizes do Brasil de Sérgio Buarque de Holanda. Não será exagerado afirmar que esta linha de ensaio, - em que se combinam com felicidade maior ou menor a imaginação e observação, a ciência e a arte - constitui o traço mais característico e original de nosso pensamento."

5 This approach contrasted with the deliberately dogmatic early films of the Centro Popular de Cultura (which Soares was a part of), such as Cinco Vezes Favela (1962), and with the "sociological" model of documentary that Jean-Claude Bernardet identified as largely characterizing Brazilian documentary of the 1960s, using as examples films such as Leon Hirszman's Maioria Absoluta (1964), Geraldo Sarno's Viramundo (1965), and Maurice Capovilla's Subterrâneas do Futebol -- the latter two Farkas productions. Those films' prominence in Bernardet's analysis led to a broader association between the Farkas productions and this style of documentary, in which, by Bernardet's analysis, the voice of the masses was put to use to serve the filmmaker's broader argument, generally expressed through voiceover - the "voz do saber," or voice of knowledge. The style, in turn, turned those subjects into objects of the filmmaker. O Homem de Couro reveals the extent to which Soares's work, and the Farkas films more broadly, should not be generalized as that particular style of documentary. For more on this see, for example, Cury, 23-24, and Ramos, 2007

6 Original: "sentimentos profundos e originais a respeito do próprio aboiador, da sua história e do mundo que o cerca."
} 
Soares's films have yet to be considered in light of da Cunha's work, or much at all in their own right. That is partly due to an imbalance in the historiography of Brazilian film, which has favored analysis of feature-length box-office or art-house favorites. It is also partly due to the context in which Soares made his documentaries. Soares formed part of a group of directors whose films Thomaz Farkas produced. In 1960, Farkas, whose family had immigrated to Brazil from Hungary when he was a young boy, inherited his father's photography shop, Fotóptica, which had grown to be the largest in São Paulo, and quickly began purchasing the equipment that transformed filmmaking (LUCAS, 2012, p. 172). He was experimenting with his new Nagra tape recorder and $16 \mathrm{~mm}$ camera in early 1964, when conservative officers ousted president João Goulart and installed themselves in power (CAPOVILLA, 2013). In the post-coup environment, Farkas offered his money, equipment, influence and inspiration to several young filmmakers who found themselves at loose ends and whose political visions matched his own (THOMAZ..., 2004).

Soares, Geraldo Sarno, and Sergio Muniz formed the core of this group of directors. Together with professors at the University of São Paulo's Instituto de Estudos Brasileiros (IEB) - Maria Isaura Pereira de Queiroz, Aderaldo Castelo, and Cavalcante Proença, among others - the group pursued a documentary-film project that would help, as Farkas put it, "lead the Brazilian people to discover their own identity" (FARKAS, 2006, p. 16).7 They envisioned an audiovisual version of the Brasiliana book series, published between 1931 and '95, which analyzed Brazil from diverse angles: history, politics, economics; culture, botany, geography (CURY, 2015 , p. 37; SOBRINHO, 2008, p. 159). In the post-coup environment, explicitly political documentaries were out of the question (as the repression of Eduardo Coutinho's production of Cabra marcada para morrer had made clear), so the group focused their efforts on popular culture (THOMAZ..., 2004).
Farkas hoped the documentaries could be shown in schools. Before late 1968 and Ato Institucional 5, the most repressive of the military government's decrees, public schools had a budget for purchasing such materials, and many had $16 \mathrm{~mm}$ projectors. He also hoped to cultivate a television market for such documentaries both in Brazil and abroad. (As it turned out, producers with Brazil's TV Cultura rejected the documentaries for showing "muita miséria," or too much poverty, Farkas later recalled [THOMAZ..., 2004]). Farkas and Muniz spearheaded the creation of a short-lived Documentary Film Production Department at IEB, and Farkas and Sarno got IEB approval for the project "Research and documentaries about popular culture of the Northeast," which involved IEB's co-production of the documentaries (SOBRINHO, 2008, p. 159). IEB support dissolved by 1968, however, victim of the political circumstances of the dictatorship, so Farkas fully sponsored the productions.

The filmmakers who worked with Farkas have in turn mostly been analyzed as a unified group. In 1997, a new name perhaps reinforced that historiographical trend. That year, Muniz organized a retrospective of the Farkas productions. He collected brief written commentaries from the filmmakers, including Eduardo Escorel, who made the lighthearted remark that, "Before the Caravana Holiday that Carlos Diegues canonized in Bye Bye Brasil, there was another caravan that departed from São Paulo to comb the Northeast. It was the Caravana Farkas, fruit of the generosity of Thomaz Farkas" (CCBB, 1997, p. 12). ${ }^{8}$ The name stuck, and as Escorel has pointed out, certain directors felt their individual contributions were neglected because of it (ESCOREL, 2012). Sarno in particular expressed frustration about "what the critics and publicists do with things, dismembering my films and packaging them in a disorganized fashion, 'The Farkas Caravan!,' all together, you see?" (SARNO, 2015). ${ }^{9}$ While

\footnotetext{
Original: "levar o povo brasileiro a descobrir sua própria identidade."

Original: "Antes da Caravana Holiday que Carlos Diegues consagrou em Bye Bye Brasil, houve outra que partiu de São Paulo para esquadrinhar o Nordeste. Foi a Caravana Farkas, fruto da generosidade de Thomaz Farkas."

9 Original: "quando eu vejo hoje o pessoal da crítica e na divulgação que fazem das coisas, desmembrarem os meus filmes e colocarem de maneira desorganizada. A 'Caravana Farkas!', ai junta, entendeu?"
} 
this packaging of the documentarians has been analytically helpful for considering the importance of their larger project, it has distracted from the directors' individual aims and approaches. The analysis below begins to address that gap by considering Soares's connections to Canudos and Os Sertões, and his documentary O Homem de Couro. The research is based on close analysis of the film and Os Sertões, primary and secondary literature about Soares and the Farkas Caravan, and my conversations with Eduardo Escorel and Tom Farkas, Farkas's grandson.

\section{"Fruit of Rural Bahian Customs": Paulo Gil Soares's Early Inspirations}

Soares had the pedigree to put da Cunha's heroes of the Bahian sertão onscreen. The director called himself the "fruit of rural Bahian customs,"10 introducing himself to one reporter in 1966 as "Paulo Gil de Andrada Soares: Andrada from cattle and goat breeders from the Bahian agreste; Soares, from old tobacco exporters from the Vale do Paraguassu, a colonial city of the Bahian recôncavo with lots of sagas of heroic figures" (ALENCAR, 1966). ${ }^{11}$ He revealed sentimental attachment to his roots in the deep northeast.

Until the early 1960s, Soares had been an aspiring writer. As a teen he wrote poetry, fiction and plays, and in high school at Salvador's Colégio Central he found friends with similar interests: Glauber Rocha, Fernando da Rocha Peres, and Calazans Neto. In the mid-1950s the group of up-and-coming Bahian writers and artists founded the now renowned literary and theater group Jogralescas Teatralizações Poéticas (CURY, 2015, p. 12). By 1958, Soares had published a book of poetry accompanied by Neto's woodcut prints in the style of literatura de cordel, regional chapbook literature whose images and verses appear throughout Soares's filmography, as well. At the University of Bahia (UFBA) in the late '50s,
Soares and Rocha also got to know Geraldo Sarno. Sarno shared Soares's and Rocha's fascination with promoting northeastern folk art, an interest stoked by the Italian-born architect Lina Bo Bardi, who lived in Salvador from 1958-64 and wrote an influential column in Diário de Notícias, where Rocha and Soares also worked as journalists (SARNO, 2006, p. 21).

In his journalistic work, Soares honed a denunciatory style reminiscent of da Cunha's. It would become a distinguishing feature of his cinematic voice (AYMORE, 1965; CURY, 2015, p. 41). And da Cunha's influence was even clearer in Soares's art: By 1961, the UFBA theater had produced his first play, "Evangelho de Couro" (Gospel of Leather), which depicted the last survivors of the War of Canudos (ALENCAR, 1966).

Soares said it was Rocha who convinced him to shift his energies from journalism to cinema (ALENCAR, 1966). In 1963, the pair traveled to Monte Santo, Bahia, the site of the Canudos massacre, to shoot Deus e o Diabo na Terra do Sol (Black God, White Devil), a film about a ranch hand, Manuel, who is cheated by his landlord, kills him, and flees into the hands of a messianic figure, Sebastião, and the cangaceiro Corisco. ${ }^{12}$ Verses sung by a cego cantador $^{13}$ help conduct the narrative, much like in Soares's later work. Soares co-wrote that film, and also served as assistant director, scenographer, and costume designer. The film's deep connections to Os Sertões have been well analyzed, most notably by Ismail Xavier; yet because of the critical tendency to celebrate directors as the sole force behind their films, Soares's participation has received little attention. Meanwhile, in Monte Santo, Soares shot his first documentary - Terra Triste - about "man and the land [in the sertão] when there's not a drought," as he put it. That film appears to have never been finished (ALENCAR, 1966; CURY, 13).

Soares and Rocha shot Deus e o Diabo just

\footnotetext{
10 Original: "fruto de costumes rurais baianos."

1 Original: "Paulo Gil de Andrada Soares. Andrada de criadores de bois e cabras, na zona do agreste da Bahia; Soares, de antigos exportadores de fumo, do Vale do Paraguassu, cidade colonial do Recôncavo baiano com muita saga de gente heróica."

12 Cangaceiros were rural bandits of the northeastern backlands, prominent in the 1920 s and 30 , and a source of seemingly endless inspiration and fascination in Brazilian (and even international) folk art and popular imagination.

${ }_{13}$ "Cego cantador" refers to a sort of blind wandering troubadour who still performed throughout parts of the rural northeast in the 1960 s and 70 s.
} 
before the military coup, and the film soon came to represent the pre-coup teleology affirming the inevitability of revolution in the northeast. Instead, from 31 March to 1 April 1964, the military took over, with little response from the masses who had presumably been primed for revolution. Leftists with any public presence found themselves under the threat of persecution. Seeking greater anonymity than Salvador provided, Soares left for Rio de Janeiro, following Rocha. Sarno, who had spent the previous year in Cuba studying cinema at ICAIC, left for the even greater anonymity of São Paulo (SARNO, 2015).

\section{Paulo Gil Soares and the Farkas Caravan}

In Rio, as is often the case, Soares's big break came at a boteco, a small neighborhood bar. Not long after the coup, Soares ran into Farkas having beers in Copacabana and pitched his idea for a documentary that would "demystify the figure of cangaçeiro." Soares hoped to investigate verses he had heard a family domestic worker recite when he was a boy, recounting the duel between Zé Rufino, the military police officer known as $O$ Matador de Cangaceiros (the Cangaceiro Slayer), and Corisco (SOARES, 1984, p. 12; CURY, 2015, p. 29). Farkas agreed on the spot to produce the documentary. Memória do Cangaço (1964) was Soares's first documentary to be completed, and also the first to incorporate Benjamin Abrãhao's 1936 footage of the most notorious cangaceiro couple, Lampião and Maria Bonita.

Memória do Cangaço represents a bridge between Soares's early work - with journalism, popular poetry and plays, and with Rocha -- and his later films made with the Caravan in three keyways. Like Deus e o Diabo, Memória do Cangaço portrays the cangaço as a parallel to Sebastianism. To Soares's sympathetic mind, both were practically inevitable responses to the exploitative, semifeudal way of life in the sertão. That stance is made explicit from the opening narration: "Along with religious rebellions, at the end of the last century the first groups of cangaçeiros emerged in the backlands, and they would carry out in the northeast feats of heroism and benevolence, standing up to the agrarian organizations and their most constant ally - the rural police guard."14 Soares would probe those themes more deeply in his later films with the Caravan.

Second, the film attacks pseudoscientific explanations for unrest in the northeast. Such theories infused da Cunha's turn-of-the-century work and still held sway among some scholars in 1960 s Brazil. Early on in Memória do Cangaço, Soares asks the question that drives the film: "But what's the origin of the cangaceiros?"15 The film cuts to an interview with Dr. Estácio de Lima, then professor of medicine at the University of Bahia and director of its Museum of Anthropology, where the heads of the most famous cangaceiros are later shown on display. Lima offers an explanation that sounds lifted from a turn-of-the-century textbook. Geographical and climatological features contributed, he says, but the central cause of the cangaço was the endocrinology and "morphology" of the sertanejo himself. Certain glands predisposed the cangaceiro to rebel, the aging white professor informs with easy confidence from his office chair. (These included, by Lima's account, the thyroid and the testicles). What's more, fat men would never have entered the cangaço, because they "love life"; thin, wiry men, resentful by nature, were especially prone.

Soares proceeds to expose the absurdity of the professor's claims. "Let's hear from one of those men,"16 he says, and appears on screen speaking with the vaqueiro Gregório, whom we might consider a real-life representation of the desperate Manuel in Deus e o Diabo. Soares interviews Gregório astride his horse as the latter presumably prepares to go out to the campo, a scene that prefigures a key scene in O Homem de Couro. There is no gallantry, however, in this film's portrayal of the vaqueiro. Gregório offers laconic,

\footnotetext{
14 Original: "Além das rebeliões de caráter religioso, com o fim do século passado surgiram no interior os primeiros grupos de cangaçeiros, que viriam construir no nordeste gestas de heroismo e bondade, enfrentando as organizações agrárias e sua aliada mais constante - a volante policial."

15 Original: "Mas qual a origem dos cangaceiros?"

16 Original: "Ouçamos um desses homens."
} 
tragic answers to the filmmaker's questions: He's been a vaqueiro for twenty years; no, the cattle aren't his; no, he doesn't earn money (only "se tiver sorte," if I'm lucky, he says); ...no, he cannot read or write; no, there are no schools in the region; no, there are no hospitals in the region; no, he's not married, he's widowed; yes, his late wife took medicine -- some dubious popular remedy like those peddled at the local feiras. Where Estácio de Lima, like da Cunha, offered pseudoscientific explanations and generalizations, Soares highlights these dire circumstances, so distant from the day-to-day life of the urban middle class.

The introduction of Gregório as "one of those men" reveals a third key feature that prefigures Farkas's later films, including $O$ Homem de Couro: a blurring of past and present (CURY, 2015, p. 75). In theory, Estácio de Lima was talking about the early twentieth century, up through the 1930s. But Soares spliced that interview together with shots not only of Lampião and his associates, but also of the 1960s northeast and a contemporary vaqueiro, conveying the persistence of ageold injustices. As Gregório rides off, Soares's narration recalls both Deus e o Diabo and Os Sertões: "Entirely alone, the sertanejo is a man abandoned to fend for himself. Nothing remains for him but desperation and rebellion."17

Edited together with the other three shorts produced by Farkas in 1964/65 - Subterrâneos do futebol (Maurice Capovilla), Nossa Escola de Samba (Horácio Gimenez), and Viramundo (Geraldo Sarno) - Memória do Cangaço formed part of the feature-length Brasil Verdade, which was screened at the First International Film Festival in Rio de Janeiro in 1965. Memória do Cangaço won that festival's Gaivota de Ouro and the praise of renowned French director Jean Rouch, the pioneer of cinéma vérité who was in Rio to participate on the festival's jury. That favorable reception further encouraged Farkas and the directors involved to continue their documentary film experiment (RAMOS, 2007, p. 29).

In 1967, when Soares was working with Rocha on Terra em Transe and on his own first featurelength film, Proezas do Satanás na vila do levae-traz, a film also set in rural Bahia and driven largely by popular verse, Farkas, Sarno, and Paulo Rufino made an exploratory trip through the northeast, returning with material for at least one documentary, Vitalino Lampião (RAMOS, 2007, p. 30). ${ }^{18}$ After their plan to work with IEB fell through in 1968, Farkas sponsored a larger group - Soares, Sarno, Muniz, Edgardo Pallero (executive production), Sidney Paiva Lopes (direct sound), Affonso Beato (photography), Lauro Escorel (photography), and himself - which departed in March 1968 for a two-month tour of the northeast. Together with the 1967 trip, this "second phase" of the Farkas Caravan, the phase that originally inspired that name, resulted in nineteen documentaries: seven by Soares, nine by Sarno, two by Muniz, and one by Eduardo Escorel.19

Soares's seven films revolve around the universe of work in the backlands. Most depict the civilização do couro (civilization of leather), ${ }^{20}$ with the exception of Erva Bruxa (tobacco) and Frei Damião (pietism). Five of the seven, including $O$ Homem de Couro, were shot at Fazenda Jaramataia in Taperoá, Paraiba, the town where the Paraiban playwright Ariano Suassuna, an intellectual close to the project, had spent much of his childhood and set many of his plays. (Suassuna kept a home in Taperoá, which may be why the filmmakers chose to settle in there.) In Soares's text accompanying the film Jaramataia, the director calls the fazenda "symbol of the rural world of the Brazilian northeast, with its remnants of old colonial fiefdoms" (SOARES,

\footnotetext{
17 Original: "Inteiramente só, o sertanejo é um homem abandonado à sua própria sorte. Nada lhe resta se não a desesperança e a rebeldia." 18 Sarno recalled that this trip resulted in several other films: Jornal do Sertão and Os Imaginários, an assertion that is repeated in Sobrinho (2008). However, the production credits for those films include discrepant information, including Afonso Beato as photographer, which would indicate that those came from the following road trip that brought together a larger group.

19 For the division into three phases see Sobrinho, 2008. Eduardo Escorel's participation as a director was somewhat accidental, and from a separate trip around the same time. By that time. Escorel was a star editor known for his work on Terra em Transe. He recalled he only made Visão de Juazeiro because Sarno, who was committed to documenting the inauguration of the massive Padre Cicero statue in that city, was otherwise engaged at the time. See Escorel, 2012.

2o Brazilian historian Capistrano de Abreu (1853-1927) referred to the sociocultural formation of the northeast as the "civilização do couro," or civilization of leather.
} 
1970). ${ }^{21}$ The colonial government imported cattle for fazendas like this one, Soares explains, establishing across the northeastern backlands the "civilization of leather, an economy entirely dominated by cattle [ciclo do gado] and the utilization of their subproducts," with "regions dominated by landowners who had power of life and death over their tenants" (SOARES, 1970). ${ }^{22}$

Most of Soares's films adopt that overtly denunciatory tone toward the northeastern social order. They are filled with what Joyce Cury has called "indicios de pobreza" (markers of poverty) analogue to the "indicios de riqueza" that Eduardo Morettin has identified as a defining feature of early cinematic production in Brazil (CURY, 2015, p. 45). Jaramataia features interviews with downtrodden farmhands and vaqueiros that range from sad to pathetic. A mão do homem and A morte do boi, shot between Jaramataia and a slaughterhouse in Feira de Santana, Bahia, show destitute laborers slaughtering cattle and tanning hides in primitive conditions, in the "most unbelievable absence of any sanitary control" (A MORTE..., 1969/70). Men walk barefoot through blood pooling around butchered oxen; children pick at carcasses, and onlookers rush to collect the blood to drink, guided by a popular notion that warm ox blood cures pulmonary diseases (A MORTE..., 1969/70).

O Homem de Couro strikes a remarkably different tone. The film documents in arresting detail a way of life built entirely around a revered profession that is undergoing dramatic and inauspicious changes under the authoritarian regime. But rather than using didactic voiceover or depressing scenes to probe those shifts, Soares made a monument to that vaqueiro way of life, a renewal and revision of the vaqueiro's heroic depiction in Os Sertões and in literatura de cordel, local epic verses celebrating the breathtaking feats of vaqueiros, cangaceiros, and the animals and land that completed their universe. The narrative is driven almost entirely by those northeastern verses, connecting these 1960s-era vaqueiros to their forebears mythicized in those rhymes encapsulating centuries of Brazilian history. The film in turn celebrates the persistence of that legendary past. We see long sequences of the vaqueiros' bravura on horseback, hear about their intimacy with their work animals, and hear their work songs, aboios honed and passed down for generations, essential tools for their work. Yet melancholy northeastern verses that open and close the film meanwhile create a pervasive atmosphere of doubt about our hero's future in this late-1960s authoritarian context.

\section{O Homem de Couro (1969/70): Aristeia of a Brazilian Folk Hero}

The first thing we see as the film opens is a western-style shot of a vaqueiro, who later introduces himself as Zé Galego, standing in a wattle-and-daub shed, an enduring symbol of the sertão. The early morning light enhances the varying tones of matte bronze in the frame: the dried earth walls, the tanned leather accoutrements resting on rudimentary trestles, and the vaqueiro's deeply bronzed skin itself.

The opening sequence reveals the clearest connection to da Cunha's work, and the first five minutes of the film serve as a sort of thesis that is developed throughout. In the opening shot, Zé Galego stares expectantly to the side of the camera, waiting for his signal to begin getting dressed. The shot immediately evokes the disconnect between the advanced camera equipment -- and the men behind it -- and the sertanejo, the fundamental disconnect that da Cunha probed in his work. When Galego receives the sign to go ahead, the corners of his mouth twitch into the hint of a smile and he dresses for work. He glances occasionally toward the camera, as if seeking approval, as Soares describes each piece of leather armor and its purpose. ${ }^{23}$

\footnotetext{
21 Original: "o simbolo do mundo rural do nordeste brasileiro"; "resquícios dos antigos feudos coloniais."

22 Original: "civilização do couro, uma economia inteiramente dominada pelo ciclo do gado e do aproveitamento dos seus sub-produtos, regiões dominadas pelos proprietários que tinham poder de vida e morte sobre os moradores."

23 Aside from Escorel, Soares was the only director of the Farkas crew to narrate his films himself; the effect is to create a more personal connection between filmmaker, subject, and audience. See Cury, 2015, p. 64.
} 
Cury has described this scene as a moment of informative-pedagogical voiceover (CURY, 2015, p. 123). The narration might also, however, be considered an adapted version of da Cunha's arming scene in Os Sertões. In ancient epics like the Iliad, a work da Cunha explicitly invoked, a hero's aristeia, or scene of glory, always begins with an arming scene, and most often ends with the hero's death. The ill-fated hero of da Cunha's epic was the sertanejo, defender of what da Cunha called the jagunços' Troia de taipa (Troy of loam and straw), and da Cunha wrote that "todo sertanejo é vaqueiro" - every sertanejo is a vaqueiro. In keeping with epic convention, he included a passage that might be considered the vaqueiro's aristeia. In it, da Cunha describes the feats of the vaqueiro in his endless battle against the caatinga, and to rein in the cattle he cares for. With an acrobat's skill on the saddle, the vaqueiro breaks up stampedes and chases runaway oxen. With his aboios as powerful as a Greek hero's lyre, he soothes his charges and convinces them to follow his lead, a manifestation of the otherworldly connection between man, music and animal in this forgotten corner of Brazil. And with the same kind of solidarity in battle that brings glory to Homeric heroes, the vaqueiro rushes to aid his comrades when they face obstacles insurmountable for a single man (DA CUNHA, 2018, pp. 121-127).

Before all those scenes of bravura and glory, however, da Cunha arms his hero, who, he writes, "Aprestou-se, cedo, para a luta"24:

As vestes são uma armadura. Envolto no gibão de couro curtido, de bode ou de vaqueta; apertado no colete também de couro; calçando as perneiras, de couro curtido ainda, muito justas, cosidas às pernas e subindo até as virilhas, articuladas em joelheiras de sola; e resguardados os pés e as mãos pelas luvas e guarda-pés de pele de veado -- é como a forma grosseira de um campeador medieval desgarrado em nosso tempo (DA CUNHA, 2018, p. 119). ${ }^{25}$
Unlike the glancing bronze that earns frequent mention in Homer, the armor of da Cunha's hero is dull and dusty, "de um vermelho pardo, como se fosse de bronze flexivel, não tem cintilações, não rebrilha ferida pelo Sol. É fosca e poenta." It is armor fit for a "combatente de uma batalha sem vitórias...," da Cunha writes (2018, p. 119), a battle waged by heroes whose fates were determined centuries earlier, in the sixteenth-century division of sesmarias -- vast royal land grants soon dedicated to cattle ranching, "definadoras da feição mais durável do nosso feudalismo tacanho" (DA CUNHA, 2018, p. 107). ${ }^{26}$ Those tragic historical roots are in the foreground in Soares's Jaramataia and A mão do homem. In O Homem de Couro, however, they are soft-pedaled, while the scenes, faculties and moral qualities constituting the vaqueiro's aristeia in Os Sertões are brought to the screen. Where da Cunha presented a race (or, more accurately, a sub-race) as his hero, in Soares's film we enter the world of an individual vaqueiro. Yet it is a world still rooted in the centuries-old practices that da Cunha described.

In his text accompanying the film, Soares writes, "Não é, de resto, o vaqueiro o último cavaleiro ainda com armaduras, como se estivesse sempre pronto para antigos torneios medievais?"(SOARES, 1969/70). ${ }^{27}$ And as Zé Galego dresses, we watch him transform into that epic hero. Soares's narration of each piece of "armor" as Galego dons it is starkly reminiscent of da Cunha's:

PGS: Guardas, também chamado perneiras, para proteger as pernas contra os espinhos abundantes na flora da região. Os sapatos. chamados roló; e as esporas, para ativar a carreira do cavalo. Guarda-peito, ou peitoral, protege o busto contra os espinhos mais altos e eventuais pancadas no peito; gibão, protetor dos braços e das costas contra pancadas de galhos de árvores; as luvas, protegem as costas das mãos ao tempo em que deixam as palmas livres, para os trabalhos do campo. ${ }^{28}$

\footnotetext{
24 Prepared himself early for battle. (My translation; this line appears to have been omitted from the Lowe translation.)

"His clothing is his armor. He wears a tanned leather jacket made of goatskin or cowhide, a snug leather vest, and tight leggings with kneepads that go to his crotch. His hands and feet are protected by calfskin gloves and skin guards. He looks like a medieval knight who has wandered into the present day." See da Cunha, 2010, p. 100.

26 "This armor of his, however, is of a bronze hue and does not sparkle or shine when the sun strikes it. It is dull and dusty. It clothes a defeated soldier"; "which placed the most enduring brand on our greedy feudalism." See Da Cunha, 2010, pp. 89; 100.

27 Isn't then the vaqueiro the last armored knight, as if he were always ready for the medieval tournaments of antiquity?

28 Guardas, also called leggings, to protect the legs from the abundant thorns of the region's flora. The shoes, called rolo; and the spores, to get the horse to run. Chest guard or peitoral: protects the bust against the highest thorns and potential blows to the chest. Doublet, protector of the arms and back against blows from branches and trees; the gloves, which protect the back of the hands at the same time as they leave the palms free for the work out on the range.
} 
In the film itself, Soares does not have to call it armor, or describe its dusty matte bronze; that is all plain to the viewer. When Zé Galego finishes dressing and turns to the camera, he is the image of da Cunha's vaqueiro warrior, with all the ambivalent connotations that come with it.

Song cultivates that ambivalence about this warrior "de uma batalha sem vitórias," updated for the 1960 s. Soares's narration of the arming scene is interspersed with plaintive verses from the cantador Cego Birrão's rendition of "Despedida do Vaqueiro" (The Vaqueiro's Farewell), which begins playing as the opening credits roll. The speaker in the song, a vaqueiro defeated by drought and unlivable pay, tells his landlord he's leaving the fazenda to seek a "new profession" in the sertão. ${ }^{29}$ As Zé Galego prepares for a day out in the campo, his profession's uncertain fate is evoked not through didactic voiceover or a guided interview, but through these doleful verses: Meu patrão eu vou embora/ Da seca deus me defenda/ E talvez em sua fazenda/ Eu não apareça mais. ${ }^{30}$ These opening lines immediately introduce the viewer to central themes of the sertão: the landowner who is the patrão (a figure conspicuously absent from the documentary itself, as discussed below), and man with God against the ravages of drought.

The verses then shift to commentary on profession and income: "Talvez por causa da seca/ Ganhando pouco dinheiro/ Na profissão de vaqueiro/Sem fortuna e sem amor." ${ }^{11}$ The lyrics suggest a change in the vaqueiro way of life that IEB sociologist Maria Isaura Pereira de Queiroz made explicit in her text accompanying the film, which might have been read or distributed at Cineclube showings: By mid-century, the vaqueiro's work was undergoing a transition from payment in kind -- usually one heifer for every four born to a herd that a vaqueiro cared for (the unhonored verbal contract that sparks
Manuel's rebellion in Deus e o Diabo) - to cash payment. Money was losing value, however, while cattle continued to grow more valuable. That meant that vaqueiros who had previously enjoyed autonomy and the opportunity to accumulate cattle and become breeders themselves were now struggling to get by on paltry pay. Yet as the film reveals, song and verse persisted as an emblem of that fading autonomy, and a key to understanding an entire way of life tied so closely to esteemed work animals:

Mas vou pedir ao senhor/ Não venda o cavalo preto

Enterre o esqueleto/ Quando ele morrer um dia

Que é pra os restos dele/ Os carniveiros não comerem

E os vaqueiros se esquecerem/ de quem tanto nos servia ${ }^{32}$

The saddle is anthropomorphized in the verses that follow from Cego Birrão:

Peço a vossa senhoria /para não vender a sela Que eu campeava nela/ Nas cercas de vaquejada Deixe que ela também/ Sinta saudade de mim Numa tristeza sem fim/ lá num canto abandonada Levo saudade guardada/ do seu cavalo Xexéu As luvas e o chapéu / sapato, guarda e gibão33

The verses depict a pervasive saudade endemic to life in the sertão, and the intimate connection it fosters not only with work animals, but also with the leather tools of the trade: saddle, gloves, hat, shoes, guarda, and doublet. The painstakingly embroidered saddles are attributed mystical qualities. All of those elements connect to what we see on-screen. As a fully armed Zé Galego turns to unlace his saddle from its support beam, Soares recites verses from northeastern cordel poet Luiz da Costa Pinheiro's História do Boi Mandingueiro e o Cavalo Mistérioso: "Esta

\footnotetext{
29 The verses might be best imagined as a dictated letter to an absentee landlord: As da Cunha points out, most vaqueiros did not know their landlord personally, since most fazendeiros lived on the coast; the vaqueiros, da Cunha writes, communicated joys and disasters through letters, signed "'seu amigo e vaqueiro.'” See da Cunha, 2018, p. 123.

3o My landlord, I'm departing/May God defend me from the drought/ And perhaps on your fazenda/ I'll never show up again.

31 Perhaps on account of the drought/ Earning little money/In the cowboy profession/Without fortune and without love.

32 But I'm going to ask you not to sell the black horse/ To bury the skeleton when he dies one day/ To keep the carnivores from eating his remains/And the cowboys from forgetting he who served us so well.

33 I ask your lordship not to sell the saddle/ As I used to ride on her in the roundups/ Let her too feel saudades for me/ In an endless sorrow abandoned in a corner/ I carry with me saudade of your horse Xexéu/ The gloves and the hat, shoes, guarda, and doublet.
} 
sela eu herdei do finado meu avô/ que ele tinha herdado do velho seu trisavô."34 The popular verses could be interpreted as Galego's, blurring the line between individual and collective, past and present. Da Cunha had written, "É dificil traçar no fenômeno a linha divisória entre as tendências pessoais e as tendências coletivas: a vida resumida do homem é um capítulo instantâneo da vida de sua sociedade" (DA CUNHA, 2018, p. 145). 35 With the interspersing of popular verse, audiovisual citations of Os Sertões, and a focus on a small group of vaqueiros, Soares renews but revises that affirmation, providing depth and subjectivity that was lacking in da Cunha's depiction. Soares invites the audience to identify with a single hero, Zé Galego, and his colleagues. He meanwhile continuously conjures Galego's ties to his forebears and his larger society, and his uncertain future. What we see on the screen is a blurring of legend and contemporary reality: the vaqueiro of popular verse, the vaqueiro hero of Os Sertões, and the vaqueiro whose profession is increasingly precarious, with the transition to a cash economy and the accelerating concentration of private capital in the sertão:

Portanto meu patrão/ faz os pedidos que eu fiz que eu sairei feliz /da sua propriedade

Vô vagar de mundo afora/ e vou morar lá no sertão

viver doutra profissão $[. . .]^{36}$

As Soares recites further fragments of verses from História do boi mandingueiro - exalting saddles and horses blessed with mythic powers of speed and agility ("com esta sela o cavalo corre mais do que o vento/ tem tanta velocidade que ultrapassa o pensamento"37) - a full shot gives audiovisual expression to da Cunha's description of the horse and its armor, which immediately follows da Cunha's arming scene in Os Sertões. "A sela de montaria," da Cunha writes, "feita por ele mesmo, imita o lombilho rio-grandense, mas é mais curta e cavada, sem os apetrechos luxuosos daquele. São acessórios uma manta de pele de bode, um couro resistente, cobrindo as ancas do animal, peitorais que the resguardam o peito, e as joelheiras apresilhadas às juntas" (DA CUNHA, 2018, p. 119). ${ }^{38}$ The shot of Galego's equipped horse brings that image to the screen.

A quarter of the way into the film we are introduced to Zé Galego. A low-angle shot reinforces his larger-than-life stature as he recites his name, the fazenda he works at (Jaramataia), his salary ("quinze mil por semana, e o leite"), and his work hours ("o campo é de 6 às 6"), before opening the gate and riding off. ${ }^{39}$ In Soares's other films, we hear grim details about such a work arrangement: cattle of the sertão provide little milk because of the insufficient pasture; cash payments are less and less sufficient; farmhands and cowherds live in a situation akin to serfdom. Yet here there is no hint of pathos. Galego exudes confidence. He represents centuries of vaqueiros -- the legendary figures of Soares's native rural northeast.

Like da Cunha's portrait of the vaqueiro and the cordel verses that complement it, a good part of the film goes on to showcase scenes of bravura. The men and their horses demonstrate the same acrobatic skill, strength, and solidarity set forth in Os Sertões and in northeastern epic poetry, revealing why, as Soares wrote, "Para o público, o vaqueiro vive em clima de permanente mito" (SOARES, 1969/70). ${ }^{\circ 0}$ Galego chases, tackles and ropes runaway oxen. The task is often too much for one man, but as da Cunha writes, the vaqueiro exhibits an unfaltering solidarity that urban audiences

\footnotetext{
34 This saddle I inherited from my departed grandfather/ he had inherited it from his old great-great-grandfather.

35 "It is difficult in this case to draw the dividing line between personal and collective tendencies. The life of this man is the summary of the life of his society." See da Cunha, 2010, p. 125.

${ }_{36}$ And so my landlord carry out these requests I've made/ And I'll leave your property a happy man/ I'm going to roam the outside world and live out on the sertão/ live off some other profession..."

37 With this saddle the horse runs faster than the wind/ he has so much speed that he surpasses thought.

${ }_{38} \quad$ "The saddle, which he has made himself, is a replica of that used in the Rio Grande region but is shorter and more concave and lacking the luxurious trappings of the other. Its accessories include a weatherproof goatskin blanket that covers the haunches of his animal, a breast covering, and kneepads." See da Cunha, 2010, p. 100

39 Fifteen thousand a week, plus milk; The campo is from 6 am to $6 \mathrm{pm}$.

40 For the public, the vaqueiro exists in a permanent aura of myth.
} 
would presumably do well to appreciate: "Solidários todos, auxiliam-se incondicionalmente em todas as conjunturas." ${ }^{41}$ If a steer gives too much fight to a single vaqueiro, that vaqueiro solicits the help of his closest companheiros, "e lá seguem todos [...] rápidos, ruidosos, amigos - campeando" (DA CUNHA, 2018, p. 122).42

That is precisely what we see onscreen. As the vaqueiros round the cattle out to the campo, Soares recites verses about pegando boi (catching runaway steers) from Historia do Boi Mandingueiro. In keeping with tradition, the verses emphasize the power of the animals the vaqueiros dominate, another element that reinforces the vaqueiros' mythical stature. Together with an aboio by Aboio de Cariri exalting family skill in pegando boi, these verses form the backdrop for a collage of scenes of the vaqueiros - first one, then two, then three together - chasing, tackling and roping runaway cattle. ${ }^{43}$ We then see four vaqueiros riding side by side through an open range in an image of autonomy and solidarity, with one another and with their animals. Over the galloping rhythm of the Banda de Pifanos de Cariri, Soares recites further popular verses glorifying that exhilarating life:

$$
\begin{aligned}
& \text { O rei mandou me chama } \\
& \text { pra casá com sua fia } \\
& \text { O dote que ele me dava } \\
& \text { Orópa França e Bahia } \\
& \text { Ouro em pó e pedra fina } \\
& \text { como ninguém possuía } \\
& \text { Roupa de couro bordada } \\
& \text { com todo ouro que havia } \\
& \text { Camisa de seda cetim } \\
& \text { com botão de prataria } \\
& \text { Eu então lhe respondi }
\end{aligned}
$$

\author{
que era pouco eu não queria \\ Sou moço sou vaidoso \\ sou filho de boa familia \\ Piso no chão devagar \\ que as folhas não chia \\ Ando na flor da água \\ e a água não se arrepia \\ Minha mãe se lastimava \\ e meu pai se maldizia \\ Do campo não saio por dote \\ história de fantasia \\ O rei mandou me chama \\ pra casá com sua filha \\ O dote que ele me dava \\ eu disse que não queria. ${ }^{44}$
}

That grandiose sequence is a far cry from the sad scenes in Memória do Cangaço, Jaramataia, A Morte do Boi and A Mão do Homem. A brief sequence of interviews that follows hints at the themes touched upon in those films, however. The first opens with a close-up of a timeworn face, the oldest vaqueiro interviewed, who tells his story. After eighteen years, he has abandoned the profession: "Agora não estou mais trabalhando porque não posso," he says. "Apanhei muito de pontada de boi, coice de gado, peitada de cavalo. Teve muitas e muitas vezes de vim do mato e mandarem me buscar no carro, sem fala, num mato de pancada. Agora eu deixei porque o que eu ganhava não dava pra eu viver." 45 He gave up, in other words, not because of his injuries, but because of the pay. He offers a salary history: "Comecei ganhando 500 mil reis por semana, fiquei ganhando 700, depois, um conto, passou pra dois, e sai daqui ganhando 10 conto." 46 That was not enough to survive on anymore, he says,

\footnotetext{
41 "Cowboys are connected by a common bond of solidarity and they help each other unconditionally whenever a need arises." See da Cunha, 2010, p. 105

42 "Tens of his companions will thunder after him, yelling and crashing through the brush, beating the thickets." See da Cunha, 2010, p. 105 43 In Os Sertões, da Cunha writes that this skill is best displayed at the annual vaquejada, or roundup, and perhaps upon the filmmakers' request, before the crew left Jaramataia, the owner of the fazenda organized a vaquejada out of season, scenes from which became another of Soares's films from the trip. Vaquejada.

44 The king sent for me to wed his daughter/ the dowry he offered: 'Yerrup.' France, Bahia/ Gold dust and fine stones as no one possessed/ leather clothes stitched with all the gold there was/ Silk satin shirt with a silver button/ And I told him it was too little and I didn't want it/ I'm a young man I'm proud, son of a good family/ I step softly on the ground so the leaves don't rustle/ I walk on water lilies and the water doesn't bristle/ My mother lamented and my father cursed himself/ I won't leave the campo for a dowry, fantasy tale/ The king sent for me to wed his daughter/ The dowry he offered, I said I didn't want it.

45 Now I'm not working anymore because I can't. I took a lot of blows from the jabs of oxen, kicks from the cattle, blows on the chest from horses. There were many, many times I came from the brush and they had to get me in a car, I couldn't talk, down in the brush from a blow. Now l've stopped working because what I earned wasn't enough to live on.

46 I began earning 500 mil reis per week, went to 700, then, 1000, then 2000, and left making 10,000 mil reis.
} 
revealing how the transition to a cash economy and inflationary pressures affected the distant and marginalized lives of the sertão.

That vaqueiro's story represents an undercurrent of the documentary that the opening and closing songs reinforce. Yet the heroic tone prevails. Interspersed with their battered colleague, Galego and several other younger vaqueiros evince pride as they tell their stories, presenting and translating their universe for urban viewers. As captured in popular verse, that universe revolves around the "most talked-about" vaqueiro, the most reliable horses, the toughest steers and the cows closest to their hearts. The vaqueiros take turns explaining how they and their work animals achieve glory: Why is the most fabled vaqueiro renowned? Because "dentro da caatinga amarrava e tudo." 47 Zé Galego's favorite horse is good because it is a "cavalo de mourão, né, aquele cavalo de confiança." ${ }^{48}$ Galego appears with his dog on his saddle, praising the dog's work as better than four or five "vaqueiro ruim": "eu e ele deu, somente," he says. ${ }^{49}$

Notably absent from the film, meanwhile, is the landlord: no one is overseeing these vaqueiros' work. This too evokes da Cunha's depiction of the sertanejo hero: "O verdadeiro dono, ausente, conhece-lhes a fidelidade sem par. Não os fiscaliza" (DA CUNHA, 2018, p. 122).50 While the owner of Jaramataia appears in the eponymous film and in Erva Bruxa, in interviews that counterpose exploiter and exploited (CURY, 2015, p. 109), here he is never even mentioned. His absence reinforces the legend of the unquestioning honesty and independence of the vaqueiro, who faithfully carries out his charge day after day, generation after generation, as da Cunha wrote: "cumpre estritamente, sem juizes e sem testemunhas, o estranho contrato, que ninguem escreveu ou sugeriu."51 Such honesty must strike his urban readers as fantastical, da Cunha observes, but is a "fato vulgar, entretanto, nos sertões" (DA CUNHA, 2018, pp. 122-123)..52

Soares, however, offers subjectivity where da Cunha offered sweeping generalizations. The director explores that subjectivity especially in the film's final five minutes, when we meet Zé Galego's family and witness the aboios of the Jaramataia vaqueiros. The viewer is first taken inside Galego's rustic, sparsely appointed home, where the vaqueiro's wife and her sister are hunched over their sewing as Galego's voiceover states, "Lutando a casa é luta dura."53 Galego describes his wife's life as one of sewing and embroidering. Then the wife, who remains nameless, offers her take on their life: "Gosto muito dessa vida de vaqueiros, acho muito bonito, mas fico preocupada... mas portanto quando ele chega, eu fico feliz, porque vês que não aconteceu nada."54 The film portrays home life built around work, solidarity, and companionship, rather than modern conceptions of love, as Galego's wife makes clear. She reveals her choice for marriage was grounded in the kind of work she valued and found grace in, reinforcing that the hardest workers of the country - those whose lives were entirely defined by work - were those that continued to go unrecognized and unprotected by official channels: "Eu não casei com lavrador porque não gosto de trabalhar na roça - não gosto de aproveitar a colheita. Casei, sim, com vaqueiro, porque gosto muito de leite e acho muito bonito ver quando o gado sai do curral e quando entra na tardezinha."55

Perhaps more importantly, Galego's wife's statement about the noble life of a vaqueiro reveals the extent to which the vaqueiro myth permeates even his own household, as Soares

\footnotetext{
In the middle of the caatinga, he'd rope and everything.

Horse of the mourão (a northeastern breed), that really dependable kind.

Just the two of us are enough, alone.

"The absent owner understands their unequaled loyalty and does not oversee them." See da Cunha, 2010, p. 103

"He adheres to this strange unwritten contract, which no one has documented or enforced, without judges or witnesses." See da Cunha, 2010, p. 104

${ }_{52}$ "This seems fantastic, but it is a well-known custom in the backlands." See da Cunha, 2010, p. 104.

Making (literally, "struggling for") the home is a tough battle.

I really like the vaqueiro life, I think it's very noble, but I get worried...but then when he arrives I'm happy, because you see nothing happened.

55 I didn't marry a farm hand because I don't like working in agriculture - I don't like harvesting crops. I married, yes, a vaqueiro, because I really like milk and I think it's beautiful to see when the cattle leave the corral and when they come back in the late afternoon.
} 
observed in his text accompanying the film $(1969 / 70)$. This is also captured through shots of Galego's young sons, who rope calves in the yard as their father comments that when they are old enough, they will join him. Much like in Nelson Pereira dos Santos's film adaptation of Vidas Secas, and in Humberto Mauro's Aboios e cantigas, the presence of children who idolize their father and his work further establishes the vaqueiro's heroic stature not only in northeastern lore but within his home (GOMES, n/d, p. 254).

This exploration of subjectivity continues as the Jaramataia vaqueiros are featured by turns calling and calming their cattle with their aboios, displaying again the deep personal connection between the men, their song, and the animals they work with. The work songs reveal these backland vaqueiros' connection to a centuries-old transatlantic web of practices surrounding cattle. Their calls evoke those of their fellow folk heroes across the Americas, with the melismatic slides over sustained vowels from high to low registers, nasal vocal timbre, and occasional repetitive lyrics that speak directly to the cattle, to comfort and persuade them, or comment on the way of life that revolves around them. Yet the aboios that tie these vaqueiros to that vast cultural web are meanwhile highly personal, soothing the workers and the cattle at once (MEDINA \& MEDINA, 2017). In the context of 1960 s Brazilian documentary, these aboios serve to underscore the subjectivity of the vaqueiros seen onscreen.

The cattle rustle in response to the aboios as another day at Jaramataia comes to a close. The final shots show Zé Galego leading the cattle back to the corral, fading away down the same dirt trail he rides in on early in the film. These shots seem to highlight the irrepressible force of these sertanejo heroes and ultimately their uncertain future under Brazil's authoritarian regime. An aboio narrating how the death of a stoic vaqueiro brings a vast fazenda to a halt provides fitting accompaniment to that final scene. In "Morte do Vaqueiro" (Death of the Vaqueiro), after the vaqueiro's death the cattle grow depressed and the land is sold off, suggesting both the centrality of the vaqueiro to life in the sertão, and also perhaps the fate of this old-time profession:
Vou vender minha fazenda
que o vaqueiro enfaleceu
da morte dele pra cá
todo gado entristeceu
até mesmo a bezerrama
com o desgosto morreu [...]
Ele antes de morrer
pediu pra nao haver choro
Despediu-se da fazenda
e do cavalo pé-de-ouro
Abraçou-se com Carmelita
beijando o gibão de couro
Ele antes de morrer
se despediu do patrão
Dizendo pra Carmelita
De-me um aperto de mão
Deixa a vida do vaqueiro
Com uma dor no coração
Amortalharam o vaqueiro
com o terno de azulão
Levando pro cemitério
de guarda-peito e gibão
Todo gado acompanharam
Chorando atrás do caixão. ${ }^{56}$

\section{Conclusion: Achievements and Legacies of "O Homem de Couro" and the Farkas Caravan}

Paulo Gil Soares achieved three things with this documentary. First, the director who considered himself "fruit of rural Bahian customs" captured onscreen the popular heroes of his native northeast. Proud men on horseback and verses

\footnotetext{
56 I'm going to sell my fazenda since the vaqueiro died/ Ever since his death all the cattle have grown sullen/ Even the heifers died of grief/ [...] Before he died he asked that we not cry/ He bid farewell to the fazenda and the golden-hooved horse/ He embraced Carmelita kissing the leather doublet/ Before he died he bid farewell to the landlord/Saying to Carmelita give me a handshake/ He leaves the vaqueiro's life with grief in the heart/ They shrouded the vaqueiro in a bright blue suit/ Taking him to the cemetery in chest-guard and doublet/ All the cattle went along crying behind the casket.
} 
about their prowess drive the film, with sweeping landscapes and a vast blue sky ("o longo horizonte sem saida que cerca nos tabuleiros nordestinos"57 [SOARES, 1969/70]) completing the exhilarating atmosphere. Second, Soares connected the vaqueiros onscreen to the foundational national struggle of the sertanejo heroes in da Cunha's Os Sertões. Just as da Cunha dedicated pages of his denunciation of the Canudos massacre to the vaqueiros' heroism, Soares dedicated this film to celebrating that way of life within his equally denunciatory project, with clear audiovisual citations of Os Sertões. Third, Soares updated da Cunha's work in several important ways. In the interstices of this heroic depiction he captured the specific plight of the 1960s, most specifically the shift to poorly remunerated wage labor in the sertão. Also, as he had done in Memória do Cangaço, Soares gave the lie to da Cunha's biological and geographical determinism. By focusing on the life of an individual vaqueiro hero and his close associates, Soares provided subjectivity that was lacking in Os Sertões.

The film was screened at Cineclubes accompanied by debates with professors such as Maria Isaura Pereira de Queiroz and Otávio lanni. Along with other shorts from the second phase of the Caravan, known collectively as A Condição Brasileira, it was also shown at international venues such as the Grenoble Film Festival of 1973. But in the context of the military dictatorship, with cuts to school funding and the specific demands of TV producers, O Homem de Couro and the other films from the series reached a very limited audience.

The films were nonetheless foundational. Thomaz Farkas's private sponsorship of this unprecedented experiment with cinéma-vérité in Brazil's rural northeast served as a launching pad for the exploration and development of a Brazilian school of documentary film, one that carried on the "mixed genre" tradition that Antônio Cândido had identified as the most characteristic feature of Brazilian thought. Soares took the opportunity to capture traditions and struggles close to his heart, and to denounce the unequal foundations of Brazil that were at their most glaring in the northeastern backlands. The experience no doubt influenced his founding of Globo Repórter in the early 1970s. With that program, Soares achieved the goal of bringing such documentary journalism to a wider audience. In 1977, he took advantage of the platform to screen the film Antônio Conselheiro e a Guerra de Canudos. Critic Paulo Maia called the screening an "important landmark for Brazilian television," for being a "superproduction of a national program... about a part of our history that is officially somewhat marginalized"58 - and because of the fight it took to get it past the censors (MAIA, 1977). Paulo Gil Soares proved himself still committed to exploring the legacies and lessons of Canudos for those within his reach.

\section{REFERENCES}

A MÃO do Homem. Directed by Paulo Gil Soares. São Paulo: Thomaz Farkas Productions, 1969/70. (19 min.) Available at https://vimeo.com/246487862. Accessed on: Feb. $10^{\text {th }}, 2021$.

A MORTE do Boi. Directed by Paulo Gil Soares. São Paulo: Thomaz Farkas Productions, 1970.

(10 min.) Available at https://www.thomazfarkas.com/ filmes/a-morte-do-boi/. Accessed on Feb.10th, 2021.

ALENCAR, Miriam. "As proezas de Paulo Gil." Jornal do Brasil, Rio de Janeiro, Caderno B, p. 8, 1968.

Cinema Novo-última safra (II) - Memórias de um Baiano. Jornal do Brasil, Caderno B, p. 2, 1966.

AYMORE, Artur. O Cangaço segundo Paulo Gil. Jornal do Brasil, Caderno B, 1965.

BASTIDE, Roger. Brasil, terra de contrastes. São Paulo: Difel, 1959

BERNADET, Jean-Claude. Cineastas e imagens do povo São Paulo: Brasiliense, 1985.

CAPOVILLA, Maurice. Depoimento. Depoimento para CPDoc-Fundação Getúlio Vargas, 2013. Available at https://cpdoc.fgv.br/sites/default/files/memoria-documentario/maurice_capovilla/TranscricaoMauriceCapovilla_Entrevista2.pdf.

CÂNDIDO, Antônio. Literatura e Sociedade. $7^{\text {th }}$ edition. São Paulo: Companhia Editora Nacional, 1985. 
CASCUDO, Luis da Camara. Vaqueiros e cantadores. São Paulo: Itatiaia - USP, 1984.

CCBB - Centro Cultural Banco do Brasil (Rio de Janeiro-RJ). A Caravana Farkas: documentários 1964-1980. Rio de Janeiro, 1997.

CUNHA, Euclides da. Os Sertões (Edição Crítica Comemorativa). São Paulo: Ubu, 2018.

Backlands: the Canudos Campaign. Translation by Elizabeth Lowe. New York: Penguin Books, 2010.

CURY, Joyce. O Documentário de Paulo Gil Soares na Caravana Farkas: vozes, personagens, e cultura popular. Master's thesis in Imagem e Som, História e Politicas do Audiovisual, Universidade Federal de São Carlos, 2015.

ESCOREL, Eduardo. Depoimento. Depoimento para CPDoc-Fundação Getúlio Vargas, 2012. Available at http://cpdoc.fgv.br/sites/default/files/Eduardo_Escorel_Final.pdf.

FARKAS, Thomaz. Cinema documentário: um método de trabalho. PhD diss. USP, 1972.

Notas de Viagem. São Paulo: Cosac Naify, 2006

Depoimento para o documentário Thomaz Farkas, brasileiro (Walter Lima Jr., 2003).

GOMES, Thalles. A imagem cantada: aboio e cantigas, de Humberto Mauro. Boitatá: Revista de Literatura Oral e Popular da ANPOLL 247-263, n/d.

JARAMATAIA. Directed by Paulo Gil Soares. São Paulo: Thomaz Farkas Productions, 1969/70 (20 min.) Available at: https://vimeo.com/245432487. Accessed on: Feb. 10th, 2021.

LUCAS, Meize. Caravana Farkas: itinerários do Documentário Brasileiro. São Paulo: Annablume, 2012.

MAIA, Paulo. Artista Jejuno Revisita Mito. Jornal do Brasil, Caderno 2, p. 2, Apr. 21st, 1977.

MEDINA, Maria de Fátima R. Medina and Maria Aparecida R. Aboio: Poesia e canto no compasso do gado. Miscelânea p. 51-72, 2017. https://doi.org/10.5016/ msc.v21io.12.

MEMÓRIA do Cangaço. Directed by Paulo Gil Soares São Paulo: Thomaz Farkas Productions, 1964. (29 min.) Available at https://vimeo.com/230761660. Accessed on Feb. $10^{\text {th }}, 2021$

MORETTIN, Eduardo V. Dimensões históricas do documentário brasileiro no periodo silencioso. Revista Brasileira de História, São Paulo, v. 25, n. 49, p. 125152, jan.-jun. 2005. https://doi.org/10.1590/S010201882005000100007

NICHOLS, Bill. Introduction to Documentary. 3rd edition. Bloomington: Indiana University Press, 2017.

O HOMEM de Couro. Directed by Paulo Gil Soares. São Paulo: Thomaz Farkas Productions, 1969/70. (20 min.) Available at: https://www.thomazfarkas.com/filmes/o-homem-do-couro/. Accessed on Feb. 10th, 2021.
PAULO Gil Soares, o pequeno principe da Bahia. Directed by Felipe Nepomuceno. Rio de Janeiro: Urca Filmes, 2019. YouTube (25 min.) Available at https:// youtu.be/SLkozLE8w-Y). Accessed on Feb. 10 ${ }^{\text {th }}, 2021$.

QUEIROZ, Maria Isaura Pereira de. 1969/1970. O Homem de Couro. Canal Farkas. Accessed October 4 2020. https://www.thomazfarkas.com/filmes/o-homem-do-couro/.

QUEIROZ, Washington. Bahia e vaqueiros: um débito. Revista FACED 17: p. 71-84, 2010. https://doi.org/10.9771/2317-1219rf.voi17.4872.

RAMOS, Clara Leonel. As múltiplas vozes da Caravana Farkas. Master's thesis. Escola de Comunicações e Artes, Universidade de São Paulo, São Paulo, 2007.

SARNO, Geraldo. Cadernos do Sertão. Salvador: Núcleo de Cinema e Audiovisual, 2006

Depoimento. CPDoc-Fundação Getúlio Vargas. Rio de Janeiro: CPDoc-Fundação

Getúlio Vargas, 2015. Available at http://cpdoc.fgv.br/ sites/default/files/memoria-documentario/geraldo_sarno/TranscricaoFinalGeraldoSarno.pdf.

SILVA, Humberto Pereira da. Glauber Rocha: cinema estética e revolução. Jundiai: Paco Editorial, 2016. https://doi.org/10.15648/hc.28.2016.0.

SOARES, Paulo Gil. Jaramataia. Publicity material for Thomaz Farkas Filmes Culturais, Canal Farkas, 1970 Accessed October 4, 2020. https://www.thomazfarkas. com/filmes/jaramataia.

O Homem de Couro. Publicity material for Thomaz Farkas Filmes Culturais, Canal Farkas, 1969/70 Accessed on: Oct. $4^{\text {th }}, 2020$. https: //Www.thomazfarkas com/filmes/o-homem-do-couro/.

Vida, paixão e mortes de Corisco, o Diabo Louro Porto Alegre: L\&PM, 1984

SOBRINHO, Gilberto. A Caravana Farkas e o moderno documentário brasileiro. In: Estudos de Cinema Socine, edited by Gustavo Souza, Leandro Mendonça, Tunico Amancio, and Esther Hamburger, p. 155-162. São Paulo: Annablume, 2008

STAVANS, Ilan. Introduction. In: Cunha, Euclides da Os Sertões. Translation by Elizabeth Lowe. New York: Penguin Books, 2010

THOMAZ Farkas, Brasileiro. Directed by Walter Lima Jr Rio de Janeiro: Urca Filmes, 2004. (16 min.) Available at https://www.urcafilmes.com.br/doc-thomaz-farkas-brasileiro. Accessed on: Feb. 10 ${ }^{\text {th }}, 2021$.

XAVIER, Ismail. Alegorias do subdesenvolvimento: cinema novo, tropicalismo, cinema marginal. 2 ed. São Paulo: Cosac Naif, 2013

e Terra, 2001
O cinema brasileiro moderno. São Paulo: Paz 


\section{Victoria R. Broadus}

PhD Candidate in History (Brazil, Latin America) at Georgetown University Washington, D.C., United States

Mailing address:

Victoria R. Broadus

Georgetown University

3700 O St NW, 20057

Washington, DC, Estados Unidos 